\title{
Qualitative Traits, Genetic Variability and Character Association for the Potential Use in Breeding Programme of Mango (Mangifera indica L.)
}

\author{
Satyendra Singh Narvariya* and A.K. Singh \\ Department of Horticulture, College of Agriculture, G.B. Pant University of Agriculture and \\ Technology, Pantnagar 263145, U.S. Nagar, Uttarakhand, India \\ *Corresponding author
}

A B S T R A C T

Mango is an important tropical fruit crop that is thought to be native to South-eastern Asia and currently cultivated worldwide in regions with tropical and subtropical climates. However, the existing diversity in most mango producing countries is at rest poorly

Keywords

Character

Association,

Genetic variability,

Qualitative traits,

Mango

Article Info

Accepted:

15 January 2019

Available Online:

10 February 2019 implicit. The Qualitative traits are influenced by environmental factors and caused numerous synonyms. It is most important to classify the accessions into their homogeneous groups on the basis of multivariate parameters instead of using univariate method to identify the nature and structure of varieties and to avoid duplicacy of accessions. Variability existing in any crop is the basis for all crop improvement programmes. Higher the variation, greater is the improvement over base population. Hence, sufficient variability, if present in the given crop can be exploited for developing superior cultivars. The concept of heritability is important to determining whether phenotypic differences observed among various individuals are due to genetic changes or due to the effects of environmental factors. Heritability indicates the possibility and extent on which improvement can be brought about through selection. It is a useful measure for considering the ratio of genetic variance to the total variance and is genetically represented in percentage. Correlation measures the degree and direction of relationship between two or more variables. The study of character association helps breeder in fixing a selection criteria for fruit yield in parental lines such as selection will be effective in isolation than correlating the correlation of phenotypic values and subjected to change in the environment. Therefore, Qualitative traits, Genetic Variability and Character Association are essential for better use of varieties/genotypes in crop improvement programme.

\section{Introduction}

Mango (Mangifera indica L.) is the most important commercial fruit of India and belongs to the family anacardiaceae. The morphological and physico-chemical traits such as tree, leaf, inflorescence and fruit

characteristics are influenced by
environmental factors and caused numerous synonyms. It is most important to classify the accessions into their homogeneous groups on the basis of multivariate parameters instead of using univariate method to identify the nature and structure of varieties and to avoid 
duplicacy of accessions. An important way to increase productivity in any fruit crop is to first select desirable cultivars from existing variation and to use the superior types for crop improvement programmes. Therefore, Therefore, Qualitative traits, Genetic Variability and Character Association are essential for better use of varieties/genotypes in crop improvement programme.

The literature pertaining to Qualitative traits, Genetic Variability and Character Association for the potential use in breeding programme of Mango have been reviewed. The brief account of available information along with supporting evidences in fruit crops have been described under following heads and subheads.

\section{Qualitative Traits}

Genetic diversity is assessed in fruit crops based on differences in qualitative traits. This is probably due to the fact that assessment of qualitative traits does not need any sophisticated equipment; they are generally simple, rapid and inexpensive to score. In many cases, the morphological qualitative traits have been used as a powerful tool in the classification of cultivars. As such morphological traits continue to be the first step in the studies of genetic relationships in most breeding.

Morphological information is essential for understanding the ideotype performance relationships and explains the heterosis that may be enhanced if morphological measures of distances are included as an independent variable. Characterization includes use of phenotypic traits that are highly heritable and these can easily be seen and equally expressed in all environments. Phenotypic studies are very important in tree improvement as the best morphological structure influences yield (Mwase, 2007).

\section{Qualitative tree traits}

Mango tree have different types of canopies such as oblong, broadly pyramidal, semi circular and spherical type. Majumder et al., (2011) noticed that 23 genotype showed ellipsoid plant shape and the rest of the genotypes were spheroid. The mango plants under the study showed three types of growth habit i.e., spreading, upright and intermediate. However, most of the genotypes showed spreading and dense type growth habit and rest upright and intermediate in nature.

Joshi et al., (2013) identified mango cultivars which had wide range of variability in physico-chemical traits of fruit and the trees under different agro-climatic conditions. As a result, morphological traits like plant growth, bark characters, foliage density, colour and leaf characters were examined. Results showed that the minimum canopy growth was found in Amrapali followed by Dashehari. Bark surface, bark colour, foliage density, foliage colour and different leaf characters also differed from each other. Joshi et al., (2013) assessed nine mango cultivars viz., Amrapali, Bombay Green, Chausa, Dashehari, Gaurjit, Gulabkhas, Langra, Mallika and Pant Sindhuri for morphological traits.

They found that Bombay Green, Chausa and Dashehari have upright growth habit while Gaurjit, Gulabkhas and Mallika were spreading growth habit as compared to other cultivars. The medium foliage density was observed in Amrapali, Dashehari, Gaurjit and Pant Sindhu, whereas, sparse foliage density in Gaurjit and Mallika and dense foliage density in the rest cultivars. A wide variation was also observed in the colour of the foliage. The Amrapali, Dashehari, Gaurjit, Pant Sindhuri, Gulabkhas and Mallika gave green foliage, while all other genotypes produced dark green foliage. 
Singh (2014) studied qualitative traits of tree like growth habit, canopy shape, branch density and foliage density which were varied with each other. The upright growth was found in Amin, Husn-a-ra, Mallika and Safeda Lucknow; intermediate in Amarpali, Bombay Green, whereas spreading type in Bride of Russia, Khasl-ul-Khas and Jafrani Gola. Rajwana et al., (2011) evaluated 17 mango varieties for morphological characterization and found that most of the varieties had spreading/compact/erect growing habit except Camal Wala, which had drooping tree shape. Ierla et al., (2013) evaluated 103 mango accession based on Brazilian descriptors for morphological characterization and found that the growth habit of the trees were predominantly semivertical $(60.1 \%)$, with the vertical present in only $3.7 \%$ of the accessions. Krishnapillai and Wijeratnam (2016) evaluated eighteen mango varieties for characterization and determine genetic diversity among genotypes on the basis of qualitative and quantitative morphological traits. They found that most of the mango varieties showed spreading growth habit. Singh (2014) studied tree traits in 42 mango varieties and observed that upright growth habit was ascertained as in Amin, Husn-a-ra, Mallika, Safeda Lucknow, while, intermediate in Amrapali, Bombay Green, chausa, Dashehari, Langra and spreading in Bride of Russia, Haathijhool, Khas-ul-khas, Zafrani Gola etc. Ellipsoid canopy shape was observed in Amrapali, Husn-a-ra, Mallika, Rumani, Safeda Lucknow etc., while spheroid shape was in Baramasi, Bride of Russia, Bijoragarh, Zafari Gola etc.

\section{Qualitative leaf traits}

The leaf morphology has wide variability particularly for leaf shape, size, young, and leaf colour and leaf margin. Differences are due to varietal variation, climate, cultural practices and growth stages. Young leaves from different varieties can present different colour. This can vary from copper-red to purplish in colour. At maturity, the leaf colour changes to dark green and usually smells like turpentine (Fivaz, 2008). Islam and Nasir (1993) carried out an investigation to study vegetative characters of some mango cultivars (Malda, Anwar Rataul, Sindhri and Banganpalli). They reported that colour of newely emerged leaves was light reddish brown in Malda, orange green in Banganpalli, light green with brownish tinge in Anwar Rataul and Sindhi, while colour of mature leaves was Spanish green in all cultivars. The shape of the leaves was lanceolate in Sindhi, oval lanceolate in Malda and Anwar Rataul and oblong in Banganpalli; leaf apex was subacuminate in Malda and Banganpalli, acuminate in Anwar Rataul and acute in Sindhi, whereas margin of leaf was flat and entire in Malda and Sindhi respectively and slightly reflexed in remaining cultivars. Sarder et al., (1998) reported that the most of mango cultivars had tall tree growth habit except Gopalbhog and Khirsapat, which had medium growth habit.

Rajwana et al., (2011) evaluated 17 mango varieties for morphological characterization and found that differences in leaf shape and size were also observed, however, common leaf shape was lanceolate with some variability to ovate lanceolate to oval or elliptic lanceolate. Joshi et al., (2013) observed leaf variability among nine mango cultivars viz., Amrapali, Bombay Green, Chausa, Dashehari, Gaurjit, Gulabkhas, Langra, Mallika and Pant Sindhuri. The acuminate type of leaf apex was found in cultivars viz., Mallika and Amrapali, while sub-acuminate was observed in Dashehari, Gulabkhas and Langra, while Bombay Green, Chausa, Gaurjit and Pant Sindhuri had acute apex. The leaf base of Chausa and Pant Sindhuri was found rounded elliptic lanceolate in Mallika and Amrapali, ovate 
lanceolate in Chausa and Pant Sindhuri while rest of the cultivars had oval lanceolate shape. The leaf margin was found entire in Mallika, Amrapali, Dashehari and Langra, while slightly wavy leaf margin was recorded in Pant Sindhuri and rest of the cultivars had wavy margins. The nature of leaf apex was acuminate and sub-acuminate in all the cultivars except Bombay Green where it was acute. Krishnapillai and Wijeratnam (2016) evaluated eighteen mango varieties for characterization and to determine genetic diversity among genotypes on the basis of qualitative and quantitative morphological traits. They found that most of the mango varieties showed lanceolate leaf shape, acuminate leaf tip and entire leaf margin. Dark green colour mature leaves were observed in $80 \%$ of the trees where $82 \%$ of the leaves had strong fragrance. Colour of young leaves was selected as one of the important morphological traits for varietal characterization.

Ierla et al., (2013) evaluated 103 mango accession based on Brazilian descriptors for morphological characterization and found that the majority of the accessions showed anthocyanin leaf colouration (78.2\%) as well as short petioles $(77.8 \%)$. As to the predominant leaf shape, the lanceolate and oval shape was not found. As to the undulation descriptor, the edge of the leaf blade underwent a similar distribution ranging from the average to the weak with a predominance of the obtuse base shape. Singh (2014) studied leaf traits in 42 mango varieties and observed that new leaf colour varied as fluorescent green in Amrapali; coppery red in chausa, Haathijhool, Sensation, Zardalu; brownish green in Bijoragarh, Gulabkhas Green, Mithu Malda, Tamancha, etc; Light coppery brown in Gurwani; Dark coppery brown in Rahman Pasand; coppery red in Thanking Amadi and also found that ovate lanceolate leaf shape was found in Bada Malda, Bombay Green, chausa, Dashehari.

\section{Qualitative inflorescence traits}

Mango inflorescence is mainly pyramidal shape and developed on reproductive shoot called panicle. The mango inflorescence is primarily terminal and its length varies from few inches to two-three feet. The inflorescence colour change from yellow to light green with crimson patches at development stage. Variation in panicle emergence and flowering behaviour in mango hybrids were also reported by Sharma et al (1998). According to Campbell and Malo (1974), the inflorescence of the mango had a pyramidal shape, while Mukherjee (1985) mentioned a conical and pyramidal shape. Majumdar et al., (2011) noticed that the inflorescence position varied from terminal axillaries to terminal and colour in most of the varieties varied from light green to light green with red patch. The variation in flowering behaviour may be attributed to the genetic and the environmental conditions.

Rajwana et al., (2011) evaluated 17 mango varieties for morphological characterization and found that shape of inflorescence varied from pyramidal (Sufaid Chausa) to broadly pyramidal (Late Ratole no 12) conical (Kala Chausa), semi circular for Faiz Kareem and spreading for Hafeez Pasand. Ierla et al., (2013) evaluated 103 mango accession based on Brazilian descriptors for morphological characterization and found that pyramidal shape was the predominant one in most of the accessions. Krishnapillai and Wijeratnam (2016) evaluated eighteen mango varieties for characterization and determine genetic diversity among genotypes on the basis of qualitative and quantitative morphological traits. They found that the terminal position of inflorescence was a dominant morphological trait as compared to the axillary position. 
Inflorescence and flower colour showed higher variation among the varieties. Inflorescence colour was selected to identify mango varieties.

Singh (2014) studied panicle traits in 42 mango varieties and observed that Conical shape of panicle was exhibited by Amin, Langra Gorakhpur, sensation, Zafrani Gola etc., the varieties Amrapali, Kesar, Khas-ulKhas, Thanking Amadi etc. were found to have pyramidal panicle shape except Bara Malda and Duddha Peda which exihibited unsymmetrical panicle shape. Colour of primary rachis varied as dark red in Totapuri Red Small; red in Bride of Russia; light red in Bijoragarh and Bombay Green; dark pink in Bara Malda, Baramasi, Rumani and Suvarnrekha; light pink in Banarasi Betali, Haathijhool, Vanraj and sensation; pink in Rataul; pink blush in Dudha Peda and Gulabkhas; green with pink streaks in Neelum; light green in Langra, Pulgoa Darbhanga, Rahman Pasand, Safeda Lucknow and Tamancha; and green in Amrapali, Dashehari, Mithua Malda and Zardalu.

\section{Qualitative fruit traits}

Mango fruit of the different varieties varies in shape, size, appearance, colour and internal trait. Campbell (1992) reported yellow with red blush fruit skin colour in Afonsa Pair, Fernandinh, Kent and Sensation. Skin colouration of mature fruit may be due to anthocyanins that develop when tissues are exposed to light. Islam et al., (1992) observed the fruit shapes of mango varieties as oblong, ovate oblong and roundish. Kamaluddin (1967) described the colour of ripe fruits of Brindaboni and Baromashi as mostly yellow and light yellow. Haque et al., (1993) observed the varietals characteristics and colours of ripe fruits. Maximum fruits turned to yellow or greenish yellow during ripening while, Kohitur and summer behest turned to red and reddish yellow. The mature fruit colour of Bombay green was green; Carabao, Manila, Mulgoa and Arumanis were greenishyellow and Haden, Keitt and Tommy Atkins have a striking red blush as reported by Mukherjee (1997).

Sardar et al., (1998) observed wide range of variability in respect of different physicochemical characteristics of mango fruits. Skin and pulp colour of ripe fruits varied from green to yellow and yellow to orange, respectively. Kumar (2000) reported that pulp colour of the fruit was not influenced by the environment and it was controlled genetically. Anila and Radha (2003) found that oblong fruit shape and beak was absent in most of the cultivars viz., Alphonso, Prior, Muvandan, Neelum, Ratna and $\mathrm{H}-$ 151. The skin of fruit is smooth and entirely pale green or yellow marked with red patches on skin at the time of ripening (Griesbach, 2003). Much variation in fruit morphology in respect of stalk thickness, base, cavity, shape, sinus, beak, apex, surface, dots and finally fruit colour were observed by Sinha et al., (2007).

Bhuyan and Kobra (2007) reported that fruit sinus in most of the varieties was shallow and basal cavity in most of the varieties was absent. They also observed that the apex of fruit varied from round to obtuse. Singh et al., (2012) observed yellow fruit colour with red blush on the shoulder in Anami Chhalli, Choe Sindhuri, Ghassipur di Chhalli, Laddu Amb, Mahantan di Laltain, Sindhuri and Chausa. Fruit colour ranged from yellowish to light yellow, deep chrome, greenish, spinach green and dark green in rest of selected mango strains.

Sharma and Majumder (1989) suggested that red skin colour of the fruit is dominant and it has been governed by duplicate gene thereby showed various gradation of pink blush on the 
fruits in progeny population. Litz (2009) repoted that Willard and Kilichondan had attractive skin colour with excellent fruit quality and were noted as suitable for export markets in Europe where red toned skin colour mangoes with sweet taste are preferred. Ierla et al., (2013) evaluated 103 mango accession based on Brazilian descriptors for morphological characterization and found that the predominant shape of the transversal section of the fruit was large and elliptic (61.6\%). The green colour of the epidermis was most frequent $(28.8 \%)$ followed by the yellow and pinkish colour (17.3\%). The depth of cavity was absent or very low for almost $80 \%$ of the evaluated accessions, showing a similar distribution among the accessions with the prominence descriptor at the base of the pedicel. According to Iyer and Subramanyam (1979) the presence of pistilar scar deformation is a dominant character. Almost all the available colour categories were found for the fruits in accordance with the descriptors used by Brasil (2002), except for the colours, orange, purple and red and purple. Three colour categories were more frequent; yellow $(16.3 \%)$, yellow and red $(15.4 \%)$ and orange and red (15.4\%). Costa et al., (2004) also analyzed the colour of the fruits and found discrepant results, such as the accession Hilda, the colour of which was classified as reddish, different, however, from what was found in the present study and which was classified as yellow.

Another verified discrepancy was the accession like Salitre, the colour of which was classified as green and yellow. According to Chitarra and Chitarra (2005), the colouration is a quality attribute that is more attractive to the consumer, varying intensely among the fruit species and even among cultivars. Iyer (1979) found that the yellow colour dominates the orange colour, while, Chitarra and Chitarra (2005) mentioned that the variation in colouration among the cultivars of the same species is due to the difference in the concentration of pigments.

Rajwana et al., (2011) evaluated 17 mango varieties for morphological characterization and found that fruit shape and size differed from variety to variety and varied from ovate (Shahanshah) to ovate oblong (Sufaid Chausa), round ovate (Faiz Kareem), oblong lanceolate (Kala Chausa) and elliptical (Camal Wala). Irregular round shape was also observed in Bubar Wala. Four germplasm (Tube Well Wala, Chun Wala, Camal Wala \& Gola) had acute beak, while in others beak was absent or slightly prominent (Sufaid Chausa, Late Ratole No. 12 \& Joyan Wala). The mesocarp is the fleshy, edible part of the fruit that usually has a sweet and slightly turpentine flavor. When ripe, its colour varies from yellow to orange and its texture from smooth to fibrous (Haque et al., 1993; Akhter, 2013). An experiment conducted by Shirin et al., (2013) revealed that the different fruit shape were observed for different cultivars such as oblong for Alam shahi, oblong elliptic for Champa, oblong oblique for Danadar and Mirabhog, roundish for Hayati, ovate oblong for Lugnee, oblong oval for Shantu. Green with yellow skin colour was found in Alam shahi, Champa, Hayati, Lugnee and Mirabhog.

Krishnapillai and Wijeratnam (2016) evaluated eighteen mango varieties for characterization and to determine the genetic diversity among genotypes on the basis of qualitative and quantitative morphological traits and found that skin colour of ripe mango fruit varied from light yellow to orange, while 10 accessions showed pink or red mixed skin colour. Fruits were observed to be oblong in 31 mango accessions and beak was absent in 16 accessions. Stem end cavity was not observed in 46 accessions and round apex was found in 49 mango accessions. 


\section{Genetic variability}

The nature and extent of variability of the basic population is the raw material on which selection acts to evolve superior genotypes or varieties in plant breeding programme. Genetic diversity is the amount of genetic variability among individuals of varieties, populations or species (Brown, 1993). The variability exploited in breeding programme is derived from the naturally occurring variants and the wild relative of crops as well as artificially developed strains and genetic stocks by human-efforts. Mango has been reported to have extensive variability due to alloploidy, cross pollination, continuous grafting and phenotypic differences arising from varied agro-climatic conditions in different growing regions (Ravishankar et al., 2000).

The long period of domestic cultivation, cross-pollination nature, alloploidy and outcrossing have contributed to the wide genetic diversity in mango (Krishna and Singh, 2007; Mukherjee, 1972). The phenomenon of allopolyploidy is believed to have originated from amphidiploidy because differentiation of many varieties occurred primarily through gene mutations, selection and preservation of some of them through grafting (Mukherjee, 1953; Mathews and Litz, 1992; Yonemory et al., 2002). In recent times, two spontaneous tetraploid mango seedlings were identified. A tetraploid "Gomera-1" from Canary Island (Galan Sauco et al., 2001) and another one from Katrine in Australia and both are used for rootstock breeding purposes (Bally et al., 2009).The available literatures on the relevant aspect have been reviewed under the following heads:

\section{Coefficient of variation}

A measure of variation which is independent of the unit of measurement is provided by the standard deviation, expressed as percentage of mean is known as coefficient of variation. Rathod and Naik (2007) studied analysis of variance in 35 genotypes of mango for characters like fruit weight, fruit volume, fruit length, fruit width, specific gravity, peel percentage, stone $\%$, pulp $\%$, TSS, acidity, ascorbic acid, total sugar, reducing sugar and non reducing sugar and found significant variation among the genotypes for all the traits. However, the higher genotypic and phenotypic coefficient of variation were obtained for ascorbic acid, fruit volume, fruit weight, acidity, peel $\%$, stone $\%$, non reducing sugar, fruit length and reducing sugar. An experiment was carried out with 9 mango cultivars by Bhowmick and Banik (2008) to assess the genetic variability for different fruit characteristics. They found that the lowest range was recorded with acidity and highest for weight. The highest phenotypic coefficient of variation was recorded for all fruit characteristics as compare to genotypic coefficient of variation.

Nayak et al., (2013) reported that phenotypic coefficients of variation (PCV) were higher than genotypic coefficients of variation but minimum difference was noticed between them. Comparatively high degree of genotypic coefficients of variation (GCV) along with phenotypic coefficients of variation was observed in quality traits like fruit weight, fruit volume, pulp: stone ratio and total carotenoids of mango. Vasugi et al., (2013) conducted an experiment to study the genetic divergence for 19 quantitative traits among 43 indigenous mango accessions. The estimates of phenotypic and genotypic variance were quite high for fruit weight followed by vitamin $\mathrm{C}$. The genotypic coefficient of variation was more than 60 per cent for the characters like fruit weight, vitamin $\mathrm{C}$ and sugars.

Kabir (2001) reported that maximum fruit weight of Neelumbori, Mallika, Gopalbhog and Amrapali. Length, breadth and thickness 
of fruits in Amrapali were 8.62, 5.91 and 5.46 $\mathrm{cm}$, in Mallika 11.73, 7.88 and $7.01 \mathrm{~cm}$, in Neelumbori 9.26, 7.32 and $7.25 \mathrm{~cm}$ and in Gopalbhog 8.15, 6.32 and $6.03 \mathrm{~cm}$, respectively. The percent moisture in pulp was ranged from 77.11 to 86.45 depending upon Germplasm in Amrapali Mallika Neelumbori and Gopalbhog percent moisture in pulp were $78.75,82.83,81.31$ and 79.09 , respectively.

Singh and Kumar (2010) studied phenotypic and genotypic coefficient of variability for growth, yield and yield attributes and showed higher PCV than the GCV for all the characters under consideration, indicating high degree of environmental influence. The PCV ranged from 9.28 for plant girth to 44.0 for fruit yield and GCV ranged from 5.95 for plant girth to 42.26 for fruit yield. The magnitude of differences was little in respect of days to first flowering, fruiting height, fruiting length and fruit weight. Among the various characters, relatively higher PCV were observed for fruit yield, fruit weight, number of fruits and fruiting length indicating that selection based on these characters would be highly effective. Dwivedi et al., (1995) also observed that selection based on characters having higher PCV would be more effective in papaya. According to Burton (1952) a character having high value of GCV with high heritability would be more valuable in selection programme. Accordingly fruit yield, fruit weight and fruiting length were having high estimate of GCV and heritability which indicates direct selection for these characters would be effective.

Majumder et al., (2012) estimated genotypic and phenotypic variability among sixty genotypes of mango. There were also considerable differences between the genotypic and the phenotypic coefficients of variation for almost all the characters which indicated the influence of environment on the expression of these traits. Among the studied characters, GCV and PCV were high for weight of harvested fruits per plant, $\%$ fruit harvest per inflorescence, $\%$ initial fruit set per inflorescence, number of fruits per plant and number of main branches per inflorescence.

\section{Heritability and genetic advance}

The concept of heritability is important to determining whether phenotypic differences observed among various individuals are due to genetic changes or due to the effects of environmental factors. Heritability indicates the possibility and extent on which improvement can be brought about through selection. It is a useful measure for considering the ratio of genetic variance to the total variance and is genetically represented in percentage. Lush (1949) defined the heritability in broad sense that it is a ratio of genetic variance to the total variance expressed in per cent. The genetic gain is the product of heritability and selection differential expressed in terms of phenotypic standard deviation of that character, heritability and genetic advance both are the components of direct selection parameters. It is necessary to utilize heritability estimates in conjunction with selection differential differentia which indicates the expected genetic gain.

Rathod and Naik (2007) found high heritability coupled with genetic advance in mango for the traits like fruit length, fruit weight, sugars, acidity ascorbic acid, peel percentage and stone percentage indicating importance of these traits for crop improvement programme. Bhowmick et al., (2008) conducted an experiment to study heritability and genetic advance for different physico-chemical traits among nine mango genotypes. They found high heritability coupled with genetic advance for most of physico-chemical traits. Islam et al.,(2010) in 
mango reported high heritability along with high degree of genetic advance (GA) for yield per plant (95.38\% and 93.38), number of fruits per plant $(89.90 \%$ and 49.63$)$, fruit weight (99.35\% and 114.31), fruit breadth (90.14\% and 49.70), stone weight (99.05\% and 90.82), stone length (98.34\% and 51.83) and pulp:stone ratio (98.74\% and 66.34).

Nayak et al., (2013) estimated high heritability for fruit weight (0.82), fruit length $(0.70)$, fruit volume (0.80), stone width (0.71), total carotenoids (0.97) and ascorbic acids (0.83); and moderate heritability for acidity (0.58), fruit width (0.62), stone length (0.68), stone thickness (0.62), peel thickness (0.53) and total soluble solids (0.69). High heritability along with high genetic advance was estimated for fruit weight and fruit volume. Genetic parameters estimated for fruit quality traits of mango may be useful to formulate pre-selection criteria and efficient breeding strategies of mango for development of new hybrids. Heritability and genetic advance (GA) as percent mean was obtained high for the characters of fruit weight and fruit length. High heritability estimate is mainly due to additive gene effect and high genetic advance thus may be expected upon effective selection.

Majumder et al., (2012) estimated heritability and genetic advance among sixty genotypes of mango and showed considerably high heritability which ranged from 56.21 to 98.24\% and the genetic advance (as\% of mean) was high for the maximum traits. High heritability coupled with high genetic advance was observed in weight of harvested fruits per plant, $\%$ initial fruit set per inflorescence, $\%$ of flowering shoot, number of inflorescences per shoot, percent fruit harvest per inflorescence, number of main branches per inflorescence, number of fruits per plant, number of inflorescences per shoot, plant height $(\mathrm{cm})$ and percent perfect flowers which indicated that these characters were less influenced by environment confirming predominance of additive gene action and therefore, selection in favour of these characters would be feasible for yield improvement of mango.

\section{Character associations}

Correlation measures the degree and direction of relationship between two or more variables. The study of character association helps breeder in fixing a selection criteria for fruit yield in parental lines such as selection will be effective in isolation than correlating the correlation of phenotypic values and subjected to change in the environment. Several workers have been studied the correlation coefficient in fruit crop, a brief review of studies on the association of characters in fruit crop is presented below:

Gupta et al., (1996) studied correlation in mango indicate that fruit diameter had significant positive correlation with fruit weight, stone weight, stone width, seed weight and seed width, whereas, negative correlation with stone thickness as well as petiole length. The fruit weight was significant positive correlation with stone length, stone width, stone weight and seed width and seed length but negatively correlated with seed weight. Azevedo et al., (1998) studied the phenotypic and genotypic correlations among plant height and crown direction. Leaf blade length was highly significantly correlated with leaf blade width; and petiole length significantly correlated with crown north-south direction. Rathod and Naik (2007) studied genotypic and phenotypic correlation among fruit traits of mango and found that the genotypic correlation were higher than their corresponding phenotypic correlations for all the traits and also reported stone weight was highly significantly correlated with seed length, seed width and seed weight. However, it was negatively 
correlated with leaf blade width and TSS: acidity ratio. Wright et al., (2007) noticed that genotypic correlation coefficient was higher than that of phenotypic correlation coefficient for most of fruit traits. Islam et al., (2010) reported in mango that yield per plant was strongly and positively correlated with fruit weight, fruit breadth, stone weight, fruit length and pulp-stone ratio. Barhate et al., (2012) studied phenotypic and genotypic correlation coefficient between number of fruits per tree and yield and found significant positive correlation of yield with number of fruits per tree, plant height, tree spread and tree girth. Vasugi et al., (2013) noticed higher genotypic correlation than phenotypic correlation in mango and found that fruit weight was most closely associated with pulp percent, total sugar, non reducing sugar, reducing sugar and stone weight. Bhowmick et al., (2008) studied genotypic and phenotypic correlation among fruit traits of mango and found that genotypic correlation coefficient was higher than phenotypic correlation coefficient for most of characters. There was a significant positive correlation of fruit weight with pulp content, breadth and significant negative correlation with peel and acid content. Total soluble solids (TSS) showed high positive correlation with total sugar and non reducing sugar. Whereas, acidity showed high negative correlation with non reducing sugar, fruit weight, pulp content, TSS, Sugar and reducing sugar content.

Singh et al., (2012) reported that fruit weight showed significant positive correlation with fruit size, pulp weight, stone weight, peel weight, pulp content, pulp/stone ratio and stone size. However, it exhibited negative significant correlation with fruit stone content. Significant negative correlations were also recorded for fruit weight, fruit breadth, pulp weight, peel weight, pulp/stone ratio with total sugars content of the fruit. Total soluble solids in juice showed significant positive correlation with total sugars (0.88) and reducing sugars (0.62) and negative correlation with juice acid content (0.47). Akhter et al., (2013) reported that fruit diameter, rind thickness, length of segment and number of segment had positive and highly significant phenotypic association with fruit weight and also genotypic positive association. The percent fruit set had negative genotypic and phenotypic association with fruit weight.

On the basis of review, it may be concluded that qualitative traits can be used for proper characterization, grouping of genotypes and varietal identification. Genetic variability indicated that significant wide variations were observed among the mango varieties for most of the characters. The phenotypic and genotypic coefficient of variation were found higher for number of fruits per tree at harvesting, yield per tree, total carotenoid, pulp weight, fruit weight, peel weight, stone weight and pulp: stone ratio, while these were moderate to low for remaining traits. The genotypic correlation coefficient was higher than phenotypic correlation coefficient for most of the characters and yield per tree.

\section{References}

Akter, A. 2013. Fruit development and quality changes of mango varieties at different growth stages. M.Sc. Thesis, Agricultural University, Mymensingh, Bangladesh.

Anila, R. and Radha, T. 2003. Physicochemical analysis of mango varieties under Kerala conditions. J. Trop. Agri., 41(1/2): 20-22.

Azevedo, D.M.P., Crisostomo, J.R., Imeda, F.C.G. and Rossetti, A.G. 1998. Estimates of genetic correlations and correlated responses to selection in cashew (Anacardium occidentale L.). Genet. Mol. Biol., 21: 344-400. 
Bally, I.S.E., Lu, P. and Johnson, P.R. 2009. Breeding plantation tree crops. New York: Springer New York. pp. 53.

Barhate, S.G., Balasubramanyan, S., Bhalerao, R.R. and Bhalerao, P.P. 2012. Genetic diversity in mango (Mangifera indica L.) genotypic and phenotypic characterization. Int. J. Plant Sci., 7 (1): 85-89.

Bhowmick, N. and Banik, B.C. 2008. Genetic variability and correlation studies for fruit physico-chemical properties of some mango cultivars grown under new alluvial zone of West Bengal. The Asian J. Hort., 3: 346-349.

Bhuyan, M.A.J. and Kobra, K. 2007. Fruit characteristics of some uncommon mango varieties grown under Joydepur condition. Bangladesh J. Agri. Res., 32(3), 493-500.

Brasil, 2002. Standard Instructions no. 4, Instructions to apply the distinguishability, homogeneity and stability assay for mango cultivars (Mangifera indica L.). Diário Oficial [da] Republica Federativa do Brasil, Brasilia, DF, Sept. 18.

Burton, G.W. 1953. Quantitative inheritance in grasses. Proceeding $6^{\text {th }}$ Int. Grassland Cong. 1: 227-283.

Cambell, C.W. 1992. Mangoes in the United States: A yearlong supply. Procceding of the Florida State Horticulture Society, 107: 303-334.

Campbell, C. and Malo, S.E. 1974. Fruits crops fact sheet: The Mango, University of Florida and Gainesville.

Chitarra, M.I.F. and Chitarra, A.B. 2005. Postharvest of fruit and vegetables: Physiology and handling, Universidad Federal de Lavras, in Portuguese.

Costa, J.G., Assis, J.S. and Santos, C.A.F. 2004. Physical and chemical characterization of 46 accessions of mango. In: Congresso Brasileiro de Fruticultura, Florianópolis: Sociedade
Brasileira de Fruticultura, 2004. (in Portuguese)

Dwivedi, A.K., Ghanta, P.K. and Mitra, S.K. 1995. Genetic variability, heritability and genetic advance relating to some fruit characters in papaya (Carica papaya L.). South Indian Hort., 43: 7376.

Fivaz, J., Villiers, E.A. and Joubert, P.H. 2008. Botanical Aspects: The Cultivation of Mango. ARC-Institute for Tropical and Subtropical Crops. pp. 9-20.

Goulao, L., Monte-Corvo, L. and Oliveira, C. 2001. Phenetic characterization of plum cultivars by high multiplex ratio markers: Amplified Fragment Length Polymorphisms and Inter-Simple Sequence Repeats. J. Amer. Soc. Hort. Sci., 126: 72-77.

Griesbach, J. 2003. Mango book, Kenya: World Agro-forestry Centre. pp.4-6.

Gupta, P.N., Rai, M. and Lalit, B. 1996. Collection of genetic diversity of mango (Mangifera indica L.) from Uttar Pradesh. Indian J. Plant Genet. Res., 9: 81-87.

Haque, A.M.M.M., Ali, M.R., Uddin, M.R. and Hossain, A.K.M.A. 1993. Evaluation of elite mango cultivars at southern region of Bangladesh. J. Plant Breed. Genet., 6: 21-28.

Ierla, C.N., Santos, R., Santos, C.A.F. and Francisco, L.P.N. 2013. Morphological characterization of mango (Mangifera indica L.) accessions based on Brazilian adapted descriptors. J. Agri. Sci. Tech., 3: 798-806

Islam, M.N., Hossain, M.M., Ra, M., Uddin, M.S. and Rohman, M.M. 2010. Heritability, correlation and path coefficient analysis in twenty ber genotypes. Acad. J. Plant Sci., 3 (2): 92 98.

Islam, M.S., Bhuyan, M.A.J., Biswas, M., Islam, N.N. and Hossain, M.A. 1992. 
Physico-chemical characteristics of fruits of some mango cultivars. Bangladesh J. Hort., 20 (2): 1-7.

Islam, T. and Nasir, M.A. 1993. Vegetative characteristics at full grown stage of some elite mango cultivars. Pak. J. Agri. Res., 14(4): 329-334.

Iyer, C.P.A and Subramanyam, M.D. 1979. Improvement of mango by selection and hybridization. Annual report of the Indian Institute for Horticultural Research, Indian Institute for Horticultural Research, Bangalore.

Joshi, R., Kundu, M. and Singh, C.P. 2013. Morphological characters: efficient tool for identification on different mango cultivars. Environ. Eco., 31(1A): 385388.

Kabir, M.A. 2001. Studies on the physicomorphological and physico-chemical characteristics of some mango germplasm under Mymensingh conditions. M.Sc. Thesis, Bangladesh Agriculture University, Mymensingh.

Kamaluddin, A.S.M. 1967. Amer Chash (in Bangla). Published by Kamrun Nahar, 2/24 Block-B, Mohammadpur Housing Estate, Dhaka-7.

Krishna, S.K. and Singh, S.K. 2007. Biotechnological advances in mango (Mangifera indica L.) and their future implication in crop improvement: A Review. Biotechnol. Adv., 25: 223-243.

Krishnapillai, N. and Wijeratnam, W.R.S. 2016. Morphometric analysis of mango varieties in Sri Lanka. Afr. J. Crop Sci., 10(6): 784-792.

Litz, R.E. 2009. The Mango: Botany, Production and Uses. $2^{\text {nd }}$ eds. $C A B$ international, Wallingford, USA. pp. 680.

Lush, J.L. 1949. Heritability of quantitative characters in farm animals. Proc. $8^{\text {th }}$ Int. Cong. Genet., Stockholm, pp. 356-376.

Majumder, D.A.N, Hassan, L., Rahim, M.A and Kabir, M.M. 2012. Genotypic and phenotypic variability in mango
(Mangifera indica L.), Bangladesh J. Agri. Res., 37(4): 683-690.

Majumder, D.A.N., Hassan, L., Rahim, M.A. and Kabir, M.A. 2011. Studies on physio-morphology, floral biology and fruit characteristics of mango. $J$. Bangladesh Agri. Univ., 9(2): 187-199.

Majumder, D.A.N., Hassan, L., Rahim, M.A. and Kabir, M.A. 2013. Genetic diversity in mango (Mangifera indica L.) through multivariate analysis. Bangladesh $J$. Agri. Res., 38(2): 343-353.

Mathews, H. and Litz, R.E. 1992. Mango, In: Hammerschlog, F. (Ed.). Biotechnology of Perennial Fruit Crops. CAB International, UK. pp. 433-448.

Mukherjee, K.U. 1992. Introduction: Botany and Importance. In: The Mango: Botany, Production and Uses, 1 Edition, R.E. Litz. (ed.), CAB International, Wallingford UK 1-19.

Mukherjee, S.K. 1953. The mango-its botany, cultivation, uses and future improvement, especially as observed in India. Econ. Bot., 7: 130-160.

Mukherjee, S.K. 1997. Introduction: Botany and Importance. In: Litz, R.E. (Ed). The Mango. Botany, Production and Uses. Wallingford: CABI publishing. pp.13.

Mwase, W.F. 2007. Characterization of genetic diversity of Uapaca kirkiana Muell., Arg using morphological traits and molecular markers, Ph.D. Thesis, Norwegian University of Life Sciences, Department of Plant and Environmental Science.

Nayak, D., Singh, A.K. and Srivastav, M. 2013. Estimation of genetic parameters of fruit quality traits in mango hybrid population. Indian J. Hort., 70 (1): 13 17.

Rajwana, I.A., Khan, I.A., Malik, A.U., Saleem, B.A., Kahn, A.S., Ziaf, K., Anwar, R. and Amin, M. 2011. Morphological and biochemical markers for varietal characterization and 
quality assessment of potential indigenous mango (Mangifera indica L.) germplasm. Int. J. Agri. Biol., 13: 151-158.

Rathod, B. and Naik, A.G. 2007. Genetic variability, correlation, path coefficient and $\mathrm{D}^{2}$ analysis for morphological and biochemical parameters of mango fruit http:

//krishikosh.egranth.ac.in/handle/1/6486 0 . searched at 04/08/2016.

Ravishankar, K.V., Lalitha, A., Dinesh, M.R. and Anand, L. 2000. Assessment of genetic relatedness among mango cultivars of India using RAPD markers. J. Hort. Sci. Biotechnol., 75(2): 198201.

Sarder, P.K.M.A., Hossain, M.S., Islam, Khandaker, S.M.A.T. 1998. Studies on the physico-morphological characters of some popular mango cultivars. J. Agri. Sci., 25: 1-4.

Sharma, D.K. and Majumder, P.K. 1989. Inheritance in mango. Acta Hort., 231: 106-111.

Shirin, F. Zuberi, M.I. and Ghosh, G.P. 2013. Fruit characteristics of some locally important mango (Mangifera indica L.) cultivars at Chapai Nawabganj District, Bangladesh. J. Biodivers. Environ. Sci., 3 (11): 96-103.

Singh, A. 2014. Studies of morphological and physico-chemical characteristics of mango (Mangifera indica L.) varieties. Thesis, Ph.D. G.B. Pant University of Agriculture and Technology, Pantnagar.
Singh, K. and Kumar, A. 2010. Genetic Variability and Correlation Studies in Papaya under Bihar Conditions, Acta Hort., 851.

Singh, N.P., Neelima, J., Singh, G. and Gill, P.P.S. 2012. Physico-chemical Characterization of unexploited mango diversity in sub-mountain zone of Northern India. Indian J. Plant Genet. Resour. 25(3): 261-269.

Sinha, B., Singh, U.K. and Kumar, N. 2007. Yield potential and fruit morphology of some late varieties of mango. Orissa $J$. Hort., 35(2): 105-107.

Vasugi, C., Sekar, K., Dinesh, M.R., Venugopalan, R. 2013. Studies on genetic divergence in unique indigenous mango accessions of Western Ghats, Int. J. Curr. Res., 5 (9): 2494-2499.

Wright, I.J., Ackerly, D.D., Bongers, F., Harms, K.E., Manriquez, I.G., Ramos, M.M., Mazer, S.J., Landau, H.C.M., Paz, H., Pitman, N.C.A., Pooter, L., Silman M.R., Vriesendorp, C.F., Webb, C.O., Westoby, M. and Wright, J. 2008. Relationship among ecologically important dimensions of plant trait variation in even geotropically forests. Ann. Bot., 99: 1013-1015.

Yonemory, K., Honsho, C., Kanzaki, S., Eiadthong, W. and Sugiura, A. 2002. Phylogenetic relationship of Mangifera species revealed by ITS sequences of nuclear ribosomal DNA and a possibility of their hybrid origin. Plant System Evol., 231: 59- 75.

\section{How to cite this article:}

Satyendra Singh Narvariya and Singh, A.K. 2019. Qualitative Traits, Genetic Variability and Character Association for the Potential Use in Breeding Programme of Mango (Mangifera indica L.). Int.J.Curr.Microbiol.App.Sci. 8(02): 1752-1764. doi: https://doi.org/10.20546/ijcmas.2019.802.207 